\title{
PRICE STICKINESS IN US-CORN MARKET: EVIDENCE FROM DSGE-VAR SIMULATION
}

\section{Olatunji A. Shobande*}

Business School, University of Aberdeen, UK

E-mail: o.shobande.19@abdn.ac.uk / olatunji.shobande@abdn.ac.uk / olatunji.shobande@yahoo.com

\section{Oladimeji Tomiwa Shodipe}

Kansas University, USA

E-mail: otshodipe@ksu.edu

(Received: December 2020; Accepted: February 2021; Published: May 2021)

\begin{abstract}
This study examines price stickiness in the United States (US) corn market using annual series data, on the dollar price of corn per bushel, obtained from the United States Department of Agriculture (USDA) and Federal Reserve Bank of Saint Louis (FRED), between 1930 and 2017. The study implemented the Calvo price stick model based on an agent in a general equilibrium and New Keynesian type, simulated using DSGE-VAR. The approach permits the indexing formula to include expected corn inflation rather than lagged inflation. The results show that corn price inflation only persists by $2 \%$ every trading year, resulting from changes in the immediate future corn-price inflation and output-gap, respectively. The shock to stochastic term only causes a partial decline in the corn price, converging at a future date with its long-run equilibrium. The experiment confirmed that corn price fluctuations are beyond the purview of the domestic economy, and any attempt to impose price policies will offset the price setting, creating further distortions and a wider gap in the corn yield. The study provides fresh insight into the Calvo price stick model of the New Keynesian type and its use to forecast agricultural outcomes.
\end{abstract}

Keywords: supply and demand shock, policy responses, price stick, agricultural yield.

JEL Classification: E0, O11, O13

\section{Introduction}

The persistent increase in agricultural pricing has been fiercely debated among researchers, policy experts, and economists in recent years. While there is some

\footnotetext{
* Corresponding author: Olatunji A. Shobande.E-mail: o.shobande.19@abdn.ac.uk

Copyright (C) 2021 The Author(s). Published by VGWU Press

This is an Open Access article distributed under the terms of the Creative Commons BY 4.0 license (Creative Commons - Attribution 4.0 International - CC BY 4.0) which permits unrestricted use, distribution, and reproduction in any medium, provided the original author and source are credited.
} 
Shobande, O.A., Shodipe, O.T., (2021)

Price stickiness in US-corn market: evidence from DSGE-VAR simulation

consensus that fluctuation in agricultural prices is either annual or seasonal, there is less agreement on whether agricultural prices exhibit a flexible or stick pattern of fluctuation. Previous studies show that contrasting views in the literature have constrained the policy direction by policymakers. This study provides fresh insight into the Calvo price stick model of the New Keynesian type and its use to forecast agricultural outcomes in the United States (US).

For decades, as the largest producer of corn globally, the US has to be concerned about the volatility in price and provide policy intervention to stabilize the domestic market through well-designed programs such as loanable funds to farmers and inventory management to serve both domestic markets and meet global demand. Several policy strategies and programs have been designed to improve production and enhance stability in the system. For instance, the farm commodity program, consisting of direct payment, counter-cyclical payment and marketing loans are prominent among the intervention policies made by the government to improve the contribution of the market to economic growth. The intervention program began with Commodity support provisions in the Farm Security and Rural Investment Act of 2002, built on three major payments strategies: (1) annual direct payments unrelated to production or prices, (2) counter-cyclical payments that are triggered when prices are below statutorily determined target prices and (3) marketing assistance loans that offer interim financing if prices fall below statutorily determined loan prices, offering additional income support (Meade et al., 2016). The program feedback shows that farmers' participation rate was relatively low. According to Meade et al. (2016), the condition concerning the program assessment constrained their participation. Notably, individual farmers must share the risk of producing a crop and comply with conservation and planting flexibility rules before the program can be beneficial. Similarly, the embodied limitation in the commodity program, which provided payment limits per farm, constrained commercial farmers with large production prospects to assess the program.

Considering these challenges, the arguments of economists on market failure and constraints on the allocation of resources due to market imperfection became evident. The fluctuation in corn pricing affects the yield gap, limiting government intervention from bearing the entire risk accompanying production. The government also demands an optimal yield production chain to meet domestic consumption and international needs. Apart from the evident change in loan rates, affecting the price support programs by changing the payment rate, producers benefit when payments are triggered (Hart \& Babcock, 2005). Other concerns that reflect political dimension and financial costs are cumulative constraints, which further frustrate the intervention process.

46 S sciendo Studia Universitatis "Vasile Goldis" Arad. Economics Series Vol 31 Issue 2/2021 ISSN: 1584-2339; (online) ISSN: 2285 - 3065

Web: publicatii.uvvg.ro/index.php/studiaeconomia. Pages $45-63$ 
Shobande, O.A., Shodipe, O.T., (2021)

Price stickiness in US-corn market: evidence from DSGE-VAR simulation

The lacuna in the existing program has cast doubt on whether the original rationale for setting up the program was meant to enhance the economic condition and guarantee stability or to allow a monopolistic exploit by the government. Major critics raised concerns on the commodity programs and acknowledged that (1) current programs highly distort world production and trade (Burfisher \& Hopkins, 2004); (2) the levels of subsidies are high and are capitalized into land prices and rents, raising the cost of production and making the United States less competitive in the global markets (Hart \& Babcock, 2005). Despite various government policy interventions, the variability of agricultural prices, especially that of corn, has persisted. This has led to continuous debate and search for possible explanations on ways to reduce this perceived market inefficiency and enhance adequate corn supply (ODI, 2010). The question, however, is whether flexible or sticky price models can explain the disparities in the price of corn, or whether the market is inefficient due to lack of competition, resulting in an upsurge in market prices. The erosion in price might even result from speculation, leading to an erroneous price spike, further accounting for volatile yields from crops.

Given these challenges and opportunities facing corn markets in the US and the quest for domestic policy strategies to restore the performance of the sub-sector, the US Department for Agriculture with support from the International Monetary Fund (IMF) has requested a study distilling the main implications of price movement in the corn market as it affects crop yield on future agricultural exports in the US and to provide policy prescriptions to avert present food insecurity, domestically and globally.

Thus, this study uses a price sticky forecasting model to describe the subjective behavior of agricultural yield in the US corn market. We tested the responses of price against agricultural yield gap, using annual series data on the dollar price of corn per bushel obtained from the United States Department of Agriculture (USDA) and Federal Reserve Bank of Saint Louis (FRED). We examined several criteria for policy commitment by the government to improve agricultural prices, particularly the US corn market, and presented various reasons for the nonparticipation of some farmers. We further conducted a ten-year forecast on corn price fluctuations. Our results confirmed the existence of short-run fluctuations which dissipated over time lag. Our forecast experiment shows that corn price fluctuations would be relatively inflexible for the next ten years.

The rest of the paper is organized as follows: Section 2 discusses the theoretical foundation and time-series evidence of the study. Section 3 presents the theoretical framework, and data methodology is presented in Section 4, while Section 5 presents the empirical results with a conclusion. 
Shobande, O.A., Shodipe, O.T., (2021)

Price stickiness in US-corn market: evidence from DSGE-VAR simulation

\section{Literature review}

\subsection{Theoretical Framework}

There are two theoretical approaches to price-yield, cyclical and pro-cyclical fluctuations, that have underpinned the empirics in agricultural output variation. The first is the new classical approach to price, advocating perfect competition and a flexible agricultural price adjusting mechanism (Von Mouche \& Quartieri, 2013). This further stressed that the market-clearing model can offer explanations for short fluctuations and that monetary authorities can offer policy prescriptions for addressing such irregular fluctuations (Lucas, 1976; Rani, Shah, Ali, \& Rehman, 2012). The second approach is the new Keynesian view, which considers the existence of an imperfect competitive market and identifies sticky prices as a possible explanation for variation in agricultural yield. These scholars conceptualized and argued that market failure, arising from self-interest, underground economy, time-inconsistent preference (Chen, Li, \& Zeng, 2014; Schreiber \& Weber, 2016), asymmetric information (An, Deng, \& Gabriel, 2011; Calvo, 1983), and poor regulatory frameworks are major reasons for price distortions, leading to sticky prices. Assuming that nominal prices are sticky, these studies argue that monetary policy can only act as a catalyst for stimulating the economy on this premise (Anderson \& Simester, 2010; Calvo, 1983).

\subsection{Related Studies}

Regarding empirical evidence, there is long and inconclusive literature on the appropriate pattern and nature of price fluctuations. Similar challenges experienced, were also reflected in the mixed results submitted on various study environments. For instance, some studies estimated various demand response shocks and reported mixed evidence. In another example, Frankel (1986) estimated the effects of agricultural commodities on monetary policy responses using the Dornbusch overshooting model and reported that monetary policy has the potential to affect agricultural prices even though there is price flexibility.

Similarly, Adjemian and Smith (2012) estimate the general equilibrium price flexibility of demand for corn and soybeans using monthly changes in expected supply published by the USDA. They reported that the demand response to a oneyear supply shock corresponded to inverse demand elasticity. However, the author concluded that demand flexibility varies by season, inventory, time horizon, and demand composition.

Fewer studies have shown that variation in the price of the corn market is explained by the endogenous switching model of rational expectation. For example, Holt and Johnson (1989) developed and estimated a rational expectation built on pricebound variation in an endogenous switching setting model for the US corn market.

48 S sciendo Studia Universitatis "Vasile Goldis" Arad. Economics Series Vol 31 Issue 2/2021 ISSN: 1584-2339; (online) ISSN: $2285-3065$

Web: publicatii.uvvg.ro/index.php/studiaeconomia. Pages $45-63$ 
Shobande, O.A., Shodipe, O.T., (2021)

Price stickiness in US-corn market: evidence from DSGE-VAR simulation

They reported that the model specification was highly nonlinear and explained superiority in corn pricing.

Using a rational expectation competitive storage model, Peterson \& Tomek (2005) described the monthly behavior of the US corn market between 1989 and 1998. They reported that a comparable persistence and occasional spikes were observed in the tested commodity price and argued that historical samples could be misleading in short sample estimates.

Martín-Rodríguez and Cáceres-Hernández (2012) developed a seasonal model for forecasting pseudo-periodic seasonal patterns in agricultural prices. They provided evidence that the length of the season is irregular and that change in season affects the mean sample and the parametric formulation of the dynamic changes.

$\mathrm{Xia}$ and $\mathrm{Li}$ (2010) proposed and estimated consumption inertia as a new explanation for asymmetric price transmission. Inertia in consumer demand increases retailers' gains in gross profits from raising prices in response to higher wholesale prices. It reduces gains from decreasing prices in response to lower wholesale prices. They reported that consumption inertia could cause asymmetries in price transmission whereby retailers are more willing to change their prices, and change them quickly, in response to wholesale price increases as opposed to wholesale price decreases. Similarly, Adjemian and Smith (2012) confirmed that changing demand for one-period supply shock and corresponding demand elasticity and the corn-ethanol production level were directly connected with the flexibilities in the two commodities.

Tack and Ubilava (2013) estimated the effects of ENSO on US county-level corn yield distributions and found that temperature and precipitation alone are not sufficient to summarise the effect of global climate on agriculture. Their results reported that acreage-weighted aggregate impacts mask considerable spatial heterogeneity at the county level for the mean, variance, and downside risk of corn yields.

Diverse opinions, research objectives, motivations, and methods of investigation reflect and impact the various submissions of the studies presented thus far. This is expected, as scholars and their environments are different, so are institutional support and research impetus. This makes it difficult to conclude that appropriate answers have been found concerning price-yield forecasting. Therefore, considering the episodes of recurrent academic papers on the interactions of price fluctuation and crop yield in the US, it is tempting to suggest that the intellectual debate is capable of generalization. However, the contrasting evidence documented, and conclusions reached from these previous studies reviewed have triggered more problems that demand urgent inquiries. Therefore, this study will not examine just the same variables as most previous studies; as such, its empirical results will be different. 


\subsection{The Corn Market Price Movement: Some Basic Facts}

The United States Department of Agriculture's forecast for corn price is usually estimated before harvest. These forecasts are often based on the historic condition of weather and inventory level. Corn farmers and users of corn rely on these projections in forming expectations about the future market prices (Abbott, Boussios, \& Lowenberg-Deboer, 2019; Schnepf, 2006). The information set available in the pre-harvest period is then used for optimization in corn market by both farmers (sellers) and buyers of corn in the harvest and post-harvest periods. Each agent tries to minimize their loss function in setting optimal prices by leveraging on the predicted post-harvest price of the corn commodity. Market system becomes the experimental laboratory where prices are determined by expectation of the likelihood of the future prices (Abbott et al., 2019). Aside from USDA, another stream of studies has devoted time on the corn price projections in the U.S on the assumption of rational expectation estimating and predicting the behavior of corn price for post-harvest periods. Over the years, the U.S corn market has exhibited a sequence of short-term disequilibrium resulting from excessive behavior of expectations and over-speculation of corn production and supply (Arnade \& Cooper, 2013; Holt \& Johnson, 1989). While corn inventories are predictable, corn production is subject to certain constraints ${ }^{\dagger}$. Since actors in the market usually anticipate production uncertainty, prices are not expected to gravitate at the equilibrium leading to corn price volatility. In the period where harvest shortage is speculated, high price is expected (Sumner \& Mueller, 2006).

The assumption that production excess in the market is cleared by government agencies in the administration of corn market stabilization is in the least not feasible. While developing the model, the optimal price that farmers and sellers of corn would like to set in each period is assumed to be the expected ruling price in the lead year as predicted by USDA and other agencies. As hypothesized by A la Calvo (1983), not all firms (farmers) would be able to reset price at the current optimal price. This is explained in detail in the method. Assumption is also made that the interaction of supply and demand for corn determines the prices in the harvest period. The supply consists of the inventory from the beginning and the U.S corn production for the period. However, corn production cannot be guessed accurately leading to frictions in the market and price distortion.

At the earlier period, corn price is relatively stable and less affected by the oversupply at the later stage. The U.S corn demand is characterized by some level of shocks. The degree of price expectation changes is influenced by the foreign

\footnotetext{
$\dagger$ Corn productions have proven to be affected by weather condition, hybrid selection, Nitrogen $(\mathrm{N})$ fertilizers, plant population, chemicals
}

50 S sciendo Studia Universitatis "Vasile Goldis" Arad. Economics Series Vol 31 Issue 2/2021 ISSN: 1584-2339; (online) ISSN: $2285-3065$

Web: publicatii.uvvg.ro/index.php/studiaeconomia. Pages $45-63$ 
Shobande, O.A., Shodipe, O.T., (2021)

Price stickiness in US-corn market: evidence from DSGE-VAR simulation

demand for agricultural commodities (Baumeister, Ellwanger, \& Kilian, 2017). This predictability in the supply and demand sides of the U.S corn market is assumed to form some sources of price distortion and volatility across different harvest periods (Johnson \& Plott, 1989).

\section{Empirical Strategy and Modelling Conditions}

In this section, we present the empirical strategy and the Calvo price stick model used before simulation.

\subsection{Empirical Strategy}

Drawing from the intuitive work of Calvo pricing model, we derive the changes in price as a function of expected future ruling corn market price changes and the deviation of the actual corn supply and aggregate output from their market steadystate equilibrium levels (Angeletos \& Lao, 2009; Brzoza-Brzezina, Kolasa, \& Makarski, 2013). Three key inspirations are derived from this model. First, it can explicitly model and predict expectation behavior as it connects the corn priceyield setting (Calvo, 1983; Taylor, 1980; Woodford et al., 2007). Second, it provides the extent to which dynamic change in the price of corn can be predicted given the constraint imposed by macroeconomic predictors on the transmission channel. This is plausible to the partially asymmetric market information that restrains all producers to fully adjust expecting prices to remain at their level for the next trading periods (Angeletos \& Lao, 2009; Phuong, Le, \& Minford, 2005). As it is impossible for all producers to reset the price to the current level, they try to minimize their loss function (Rabanal \& Rubio-Ramírez, 2005).

\subsection{Empirical Model}

We work with Calvo model as stated as:

$$
\chi\left(P_{t}\right)=\sum_{j=0}^{\infty}(\psi \beta)^{j} E_{t}\left(p_{t}-p_{t+j}^{*}\right)^{2}
$$

$0<\beta<1, P^{*}{ }_{t+j}$ logarithm of the optimal price producer might set in the $t+j$ period if prices are able to reset to optimal.

The expression on the RHS can be broken down into compressive way

$$
\left(p_{t}-p^{*}{ }_{t+j}\right)^{2}
$$

This is defined as the loss minimization of expected losses incurred by a segment of corn producer that would not be able to adjust to optimal price in a particular period. We then assumed that, if farmers are stuck at $P_{t}$ it will be difficult to reset the price to the optimal level at $+j$. This implies that some producers face rigidity in their prices. The summation of the above is the total losses incurred for being stuck at a less optimal price. Where $\beta$ is less than one, discounted to future and 
Shobande, O.A., Shodipe, O.T., (2021)

Price stickiness in US-corn market: evidence from DSGE-VAR simulation

serves as measures of producer discount the losses. This assertion suggests that the future losses to corn yield are less than the present and more weight is allotted to the present losses than the future. While the probability that prices are likely to be rigid is denoted as $t+j$ is indicated by $\psi^{j}$.

Since the producer is fully optimistic, the price would remain fixed in the long run; the corn yield is not expected to be affected in the future periods. We define that the optimal price chosen by those producers who would be able to reset the price to the optimal level can be derived by applying the simple differentiation to minimize the above quadratic loss functions. The first derivative of equation 1 is:

$$
\begin{aligned}
& \frac{\partial \chi}{\partial p_{t}}=\chi^{\prime\left(p_{t}\right)}=2 \sum_{j=0}^{\infty}(\psi \beta)^{j} E_{t}\left(p_{t}-p^{*}{ }_{t+j}\right)=0 \\
& \sum_{j=0}^{\infty}(\psi \beta)^{j} p_{t}=\sum_{j=0}^{\infty}(\psi \beta)^{j} E_{t} p^{*}{ }_{t+j}
\end{aligned}
$$

The above is set equal to zero to show the minimum losses producer is incurring. This can be disaggregated as:

The expression of $\sum_{j=0}^{\infty}(\psi \beta)^{j}$ be simplified as $\frac{1}{1-\psi \beta}$ using mathematical proof.

The LHS of equation can be written as:

$$
\sum_{j=0}^{\infty}(\psi \beta)^{j} p_{t}=\frac{1}{1-\psi \beta} p_{t}
$$

The expression in the equation 3 can be written as:

$p_{t}=(1-\psi \beta) \sum_{j=0}^{\infty}(\psi \beta)^{j} E_{t} p^{*}{ }_{t+j}$

Playing round the expansion of the equation 3: The right-hand side can be written as $\quad \sum_{j=0}^{\infty}(\psi \beta)^{j} E_{t} p^{*}{ }_{t+j}=p^{*}{ }_{t}+(\psi \beta)^{1} E_{t} p^{*}{ }_{t+1}+(\psi \beta)^{2} E_{t} p^{*}{ }_{t+2}+$ $(\psi \beta)^{3} E_{t} p^{*}{ }_{t+3}---^{*}$

However, looking at the preceding equation, the expected price producers in one lead year can be written as:

$$
E_{t} p_{t+1}=(1-\beta) \sum_{j=0}^{\infty}(\psi \beta)^{j} E_{t} p^{*}{ }_{t+j+2}
$$

Such that equation 3 , is written as:

$(\psi \beta)^{3} E_{t} p_{t+4}^{*}$

$$
\sum_{j=0}^{\infty}(\psi \beta)^{j} E_{t} p^{*}{ }_{t+j+1}=E_{t} p^{*}+\psi \beta E_{t} p^{*}{ }_{t+2}+(\psi \beta)^{2} E_{t} p^{*}{ }_{t+3}+
$$

Multiplying equation 4 by $\varphi \beta$ and subtracting from equation 5 . The expression looks like:

52 Sciendo Studia Universitatis "Vasile Goldis" Arad. Economics Series Vol 31 Issue 2/2021 ISSN: 1584-2339; (online) ISSN: $2285-3065$

Web: publicatii.uvvg.ro/index.php/studiaeconomia. Pages $45-63$ 
Shobande, O.A., Shodipe, O.T., (2021)

Price stickiness in US-corn market: evidence from DSGE-VAR simulation

$$
\begin{aligned}
& p_{t}-\psi \beta E_{t} p_{t+1}= \\
& (1-\psi \beta) \sum_{j=0}^{\infty}(\psi \beta)^{j} E_{t} p_{t+j}{ }^{*}-(1-\psi \beta)(\psi \beta) \sum_{j=0}^{\infty}(\psi \beta)^{j} E_{t} p_{t+j+1}{ }^{*}
\end{aligned}
$$

The right hand of the equation 5 can be reduced to:

$$
\begin{aligned}
& (1-\psi \beta) \sum_{j=0}^{\infty}(\psi \beta)^{j} E_{t} p_{t+j}{ }^{*}- \\
& (1-\psi \beta)(\psi \beta) \sum_{j=0}^{\infty}(\psi \beta)^{j} E_{t} p_{t+j+1}{ }^{*}=(1-\psi \beta) p_{t+j}{ }^{*}
\end{aligned}
$$

Such that both right hand and left-hand side of the equation 5 can be reduced to:

$$
p_{t}-\psi \beta E_{t} p_{t+1}=(1-\psi \beta) p_{t}^{*}
$$

Rearranging the equation 6 we have:

$$
p_{t}=\beta E_{t} p_{t+1}+(1-\psi \beta) p_{t}^{*}
$$

The expression above is the optimal price set by individual firms who are above to reset prices. In the following, it is now assumed that producers of corn are identical such that they supply homogenous products to the market. However, another assumption made is that certain percentage of corn producers are unable to choose optimal prices at time $t$. such that the ruling corn price in period $t$ is determined by two set of producers: those that are able and those not able to choose prices at time t. That is:

$$
p^{\prime}=\psi p_{t-1}^{\prime}+(1-\psi) p_{t}
$$

Where $p^{\prime}$ is referred to an average of log price of Calvo. We can now rewrite the equation by:

$$
p_{t}=\frac{1}{(1-\psi)}\left(p^{\prime}{ }_{t}-\psi p^{\prime}{ }_{t-1}\right)
$$

The equation above depicts the price of producers who are able to reset price at time t. The persistence in this behaves will make the expected price for the reset price in the immediate future to be:

$$
E_{t} p_{t+1}=\frac{1}{(1-\psi)}\left(E_{t} p^{\prime}{ }_{t+1}-\psi p^{\prime}{ }_{t}\right)
$$

Importing and substituting equation 5, 6 and 7, we have the following expression:

$$
\frac{\psi \beta}{(1-\psi)}\left(E_{t} p^{\prime}{ }_{t+1}-\psi p^{\prime}{ }_{t}\right)+(1-\psi \beta) p^{*}{ }_{t}=\frac{1}{(1-\psi)}\left(p^{\prime}{ }_{t}-\psi p^{\prime}{ }_{t-1}\right)^{*}
$$

Re-arranging equation 8. 
Shobande, O.A., Shodipe, O.T., (2021)

Price stickiness in US-corn market: evidence from DSGE-VAR simulation

$$
\frac{\psi \beta}{(1-\psi)} E_{t} p^{\prime}{ }_{t+1}=\frac{1+\beta \psi^{2}}{(1-\psi)} p_{t}^{\prime}-(1-\psi \beta) p_{t}^{*}-\frac{\psi}{(1-\psi)} p_{t}{ }^{\prime}
$$

Performing a little arithmetic on both: That we deduct the expression $\frac{\psi \beta}{(1-\psi)} p^{\prime}{ }_{t}$ from both sides:

$$
\begin{aligned}
& \frac{\psi \beta}{(1-\psi)}\left(E_{t} p^{\prime}{ }_{t+1}-p^{\prime}{ }_{t}\right) \\
& =\frac{1+\beta \psi+\beta \psi^{2}}{(1-\psi)} p^{\prime}{ }_{t}-(1-\psi \beta) p^{*}{ }_{t}-\frac{\psi}{(1-\psi)} p_{t-1}^{\prime}{ }^{*}
\end{aligned}
$$

Intuitively, the price changes and expected price changes are derived in the above expression.

$$
\begin{gathered}
E_{t} \pi^{\prime}{ }_{t+1}=\left(E_{t} p^{\prime}{ }_{t+1}-p^{\prime}\right) \text { is expected price change and } \\
E_{t} \pi^{\prime}{ }_{t}=\left(p^{\prime}{ }_{t}+p^{\prime}{ }_{t-1}\right) \text { is the current price changes } \\
\frac{\psi \beta}{(1-\psi)} E_{t} \pi^{\prime}{ }_{t+1} \\
=\frac{(1-\psi)(1-\psi \beta)}{(1-\psi)} p^{\prime}{ }_{t}-(1-\psi \beta) p^{*}{ }_{t}+\frac{\psi}{(1-\psi)} \pi^{\prime}{ }_{t}{ }^{\prime}
\end{gathered}
$$

The above expression can also be written as:

$$
\beta E_{t} \pi^{\prime}{ }_{t+1}=\frac{(1-\psi)(1-\psi \beta)}{\psi}\left(p^{*}{ }_{t}-p^{\prime}{ }_{t}\right)-E_{t} \pi^{{ }^{\prime}}{ }_{t}^{*}
$$

Where $\left(p^{*}{ }_{t}-p^{\prime}{ }_{t}\right)$ is expressed as a proportion of output gap $\delta y$ in the industry The last equation can be expressed as:

$$
\begin{aligned}
& \pi^{\prime}{ }_{t}=E_{t} \pi^{\prime}{ }_{t+1}+\frac{(1-\psi)(1-\psi \beta)}{\psi} y^{*}{ }_{t} \\
& \pi^{\prime}{ }_{t}=E_{t} \pi^{\prime}{ }_{t+1}+\omega \theta y^{*}+\varepsilon_{t}
\end{aligned}
$$

Equation 10 shows that changes in the current price as a function of the expected future price change and the output gap in each period.

$E_{t} \pi^{\prime}{ }_{t+1}=$ the expected corn inflation resulting from variation in corn price

$y=$ is the deviation of corn output from it equilibrium position?

$\beta=$ is the parameter that explains elasticity of future change in prices

$\partial=$ is the parameter that explains elasticity of aggregate output deviation from its equilibrium position

$\omega=$ comprises set of constant parameters 
Shobande, O.A., Shodipe, O.T., (2021)

Price stickiness in US-corn market: evidence from DSGE-VAR simulation

$\theta=$ is the parameter that governs the path of corn consumption in the corn sector.

\subsection{Data and methodology}

The experimental approach used in this study is similar to that of Phuong et al. (2005), where expected corn inflation rather than lagged on inflation. In addition to the analytical model presented in section 3 , we compute the impulse responses function for the model variables under the different indexing processes in the face of temporary corn yield and expected price shocks. The intuition behind the simulation is that the expected price indexed is calculated as the necessary price increase that will absorb the unanticipated fluctuation in corn market yield.

The data used in the estimation are sourced from the United States Department of Agriculture (USDA) and Federal Reserve Bank of Saint Louis (FRED). The yearly data on the dollar price of corn per bushel are collected from 1930 to 2017. Following the United States' consumer price index, time-series prices were indexed on price in 2010 whereby year 2010 is used as the base year. The data was collected by submitting a query on the data page of USDA website. The query, both corn output and corn price index were generated. We went ahead to estimate corn market inflation using the percentage change price index from year to year. The real future year for corn in the United States is planted in the month of April and the yield period is run between August and September with exceptional cases. The growing of corn sometimes is likely to be a condition on climate factors which include but not limited to temperature and precipitation. Although the climatic condition is a predetermined factor of yield crop. On a regular basis, USDA usually published an estimate of the crop size, precisely in January after the yield period. The corn output $(\mathrm{y} 1)$ is measured in million bushels and Corn inflation $\left(\pi^{\prime}{ }_{t}\right)$ is measured by the annual percentage change in the cost of corn per bushel in a year. The expected inflation $\left(E_{t} \pi^{\prime}{ }_{t+1}\right)$ and the corn output gap $\left(y^{*}\right)$ are estimated by the in-built STATA command. We allowed the STATA to estimate the gaps in the corn output.

\section{Empirical Results}

The empirical results of the developed model in section three are presented here. In our analysis, we have used the Calvo pricing model, along with some other unobserved important variables discussed earlier. There are two observed controlled variables (corn price inflation- $\pi$ ) and corn yield (y) per bushel. The third controlled (unobserved) variable is the corn output gap. The other set of unobserved variables are the shocks (the state variable $-\mu$ and $\varepsilon \varepsilon_{t-1}$ ). Among these unobserved variables, the output gap is most important. In the current period, we assume that the state variables are constant, but they are specified to be dynamic 
Shobande, O.A., Shodipe, O.T., (2021)

Price stickiness in US-corn market: evidence from DSGE-VAR simulation

over time. This follows that the state equations are now modeled as one lead state variable as a function of the current state variable". Having established this, we summarize the two observed control variables.

Table 1 Summary: Corn Inflation

\begin{tabular}{|r|r|r|r|r|r|}
\hline Year & Obs. & Mean & Std. Dev & Min & Max \\
\hline Corn-Inf & 88 & 4.373767 & 24.00165 & -52.42719 & 69.17809 \\
\hline Yield & 88 & 87.0659 & 47.02507 & 18.6 & 176.5845 \\
\hline
\end{tabular}

Source: Author's computation

Table 1 shows the summary statistics of the corn inflation and corn yield from 1930 to 2017 . The table simply shows that corn inflation between these periods changed widely with deflation of approximately 52\% in a particular year and $69 \%$ inflation in a particular year. The average inflation was 4.37 and a high standard deviation of $24 \%$. The mean corn yield is $87 \%$. The lowest and highest corn yield for the period is $18.6 \%$ and $176.6 \%$ respectively. There was relatively low variability compared to the corn-inflation. However, the corn-price inflation was appropriately transformed. The simulation model is discussed below:

Table 2 Summary: Structural Model

\begin{tabular}{|c|r|r|r|r|}
\hline & Coef. & Std.Err. & $\mathrm{Z}$ & $\mathrm{P}>|\mathrm{z}|$ \\
\hline $\boldsymbol{\pi}_{\boldsymbol{t}+\boldsymbol{1}}$ & 0.02119 & 0.00388 & 5.46 & 0.0000 \\
\hline $\boldsymbol{y}_{\boldsymbol{t}}$ & 0.02016 & 0.00526 & 3.83 & 0.0000 \\
\hline $\boldsymbol{\mu}_{\boldsymbol{t}}$ & 0.61118 & 0.07420 & 8.24 & 0.0000 \\
\hline $\boldsymbol{\varepsilon}_{\boldsymbol{t}}$ & 38.34486 & 0.07470 & 5.13 & 0.0000 \\
\hline $\boldsymbol{s d}(\boldsymbol{e} \boldsymbol{u})_{\boldsymbol{t}}$ & 30.31604 & 4.62698 & & \\
\hline $\boldsymbol{s d}(\boldsymbol{e} \boldsymbol{\varepsilon})_{\boldsymbol{t}}$ & 8.20783 & 0.68430 & & \\
\hline
\end{tabular}

Source: Author's computation

Table 2 represents the parameters for the expected inflation $\left(\pi_{t+1}\right)$, the corn output gap $\left(y_{t}\right)$ and the current shocks in the state equations. The two fundamental parameters (expected inflation and output gap) conform to the a priori.

They were predicted to be non-negative and significant. It is important to notice that both expected inflation and output gap explained little variation of the current corn-price inflation. That is, a $1 \%$ change in expected corn-price inflation leads to $0.02 \%$ in the current inflation. $1 \%$ change in output gap also leads to $0.02 \%$. This clearly indicates that the current corn price is sticky and there seems to be no high

\$STATA Command Manual

56 Sciendo Studia Universitatis "Vasile Goldis" Arad. Economics Series Vol 31 Issue 2/2021 ISSN: 1584-2339; (online) ISSN: $2285-3065$

Web: publicatii.uvvg.ro/index.php/studiaeconomia. Pages $45-63$ 
Shobande, O.A., Shodipe, O.T., (2021)

Price stickiness in US-corn market: evidence from DSGE-VAR simulation

inflation persistence in the market. The price tends to gravitate towards its long-run equilibrium. The shocks in the market do not cause the current corn price to move wide apart from the long-run equilibrium level. Table 3 shows the effect of the state variables on the control variables.

Table 3 Effect of Shocks on Control Variables

\begin{tabular}{|c|c|c|c|c|c|}
\hline Shock & & Coef. & Std.err. & $\mathrm{Z}$ & $\mathrm{P}>|\mathrm{z}|$ \\
\hline \multirow{3}{*}{$\boldsymbol{\pi}_{\boldsymbol{t}}$} & $\mu_{t}$ & -0.01524 & 0.00186 & -8.19 & 0.000 \\
\cline { 2 - 6 } & $\varepsilon_{t}$ & 0.01794 & 0.00295 & 6.06 & 0.000 \\
\cline { 2 - 6 } & $\varepsilon_{t-1}$ & 0.00361 & 0.00110 & 3.27 & 0.001 \\
\hline \multirow{3}{*}{$\boldsymbol{y}_{\boldsymbol{t}}$} & $\mu_{t}$ & -0.74620 & 0.20292 & -3.68 & 0.000 \\
\cline { 2 - 6 } & $\varepsilon_{t}$ & 0.87442 & 0.28251 & 3.10 & 0.002 \\
\cline { 2 - 6 } & $\varepsilon_{t-1}$ & 0.17183 & 0.06691 & 2.57 & 0.010 \\
\hline \multirow{3}{*}{$\boldsymbol{y i e l d}$} & & & & & \\
\cline { 2 - 6 } & $\mu_{t}$ & 0.28081 & 0.05383 & 5.22 & 0.000 \\
\cline { 2 - 6 } & $\varepsilon_{t}$ & 0.84642 & 0.02105 & 40.19 & 0.000 \\
\cline { 2 - 6 } & $\varepsilon_{t-1}$ & 0.17034 & 0.02387 & 7.14 & 0.000 \\
\hline
\end{tabular}

Source: Author's computation

Table 3 shows the effect of the state variables on the control variables. The stochastic terms in each level of the equations affect the control variables as the Pvalues are all less than a 5\% level of significance. Inflation is negatively influenced by shocks in the output gap model, positively affected by current and lagged shocks in the yield model. This effect is also replicated in the output gap and yield equations. The significance of the parameters shows that the state variables drive changes in inflation and output gap in the market. The market performances are driven by surprises exogenous to the developed models. It is not a contradiction as the structural model already established non-inflation persistence. The shock is perceived to converge constraining the corn-price inflation to stabilize over time. This result is also revealed in the Impulse Response Function (IRF). 
Shobande, O.A., Shodipe, O.T., (2021)

Price stickiness in US-corn market: evidence from DSGE-VAR simulation

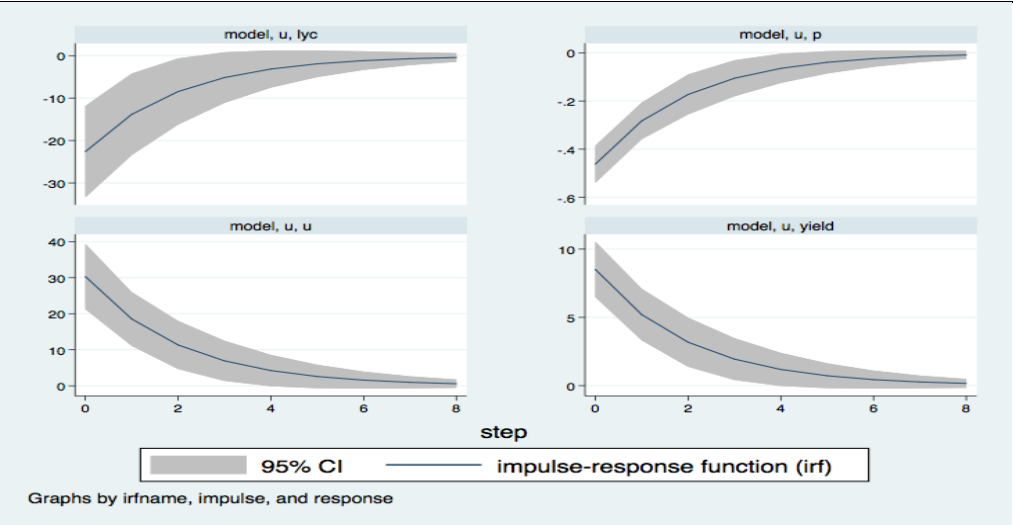

Figure 1 Impulse Response Function

Panel 1 Shows the Impulse Response Function for Structural model (Corn yield)

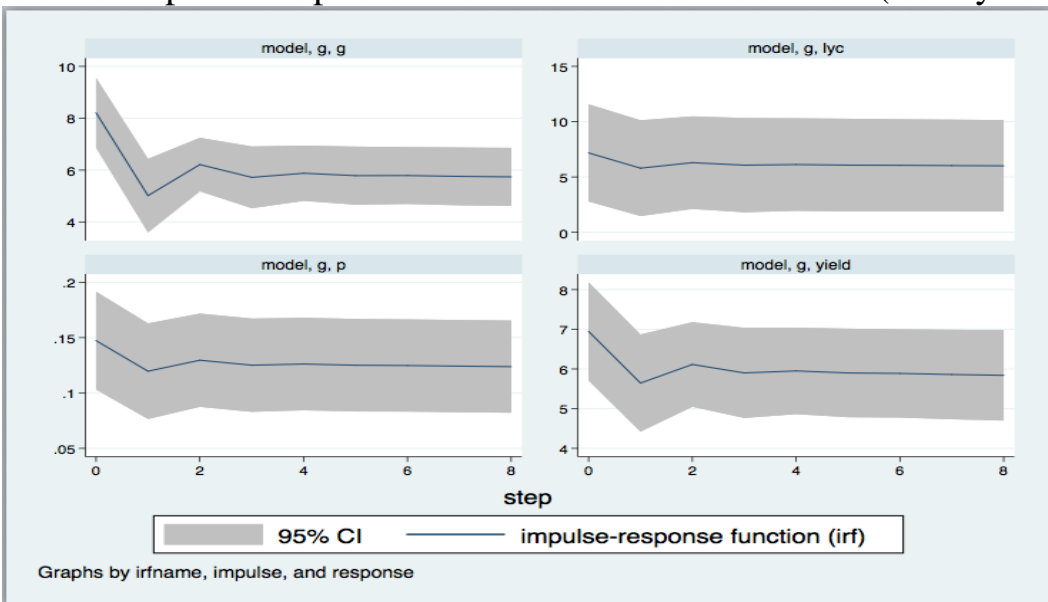

Panel 2 shows the Impulse Response Function for Structural model (Corn price). Panel 1 (our focus) reveals how the shock to stochastic term that results from changes in corn yield other than the corn price inflation. As shown in panel 1, the IRF indicates how the shock to stochastic term (u) causes an impermanent decline in the corn price inflation and later converges at future date to its long-run equilibrium. That is, the corn inflation was temporarily destabilized by the shocks to the state variables but converged to the its-steady state after some period of time. The output gap also responded to the shocks but later returned to its long-run equilibrium. The model predicts that corn-price inflation is non-persistent but converges after some period of shocks. 
Shobande, O.A., Shodipe, O.T., (2021)

Price stickiness in US-corn market: evidence from DSGE-VAR simulation

The Out of the Sample Forecast

The thrust of the study is to develop an econometric model that can predict the corn price inflation for any period horizon. The assumption that prices are sticky in the corn market seems plausible when we consider that not all farmers are capable of adjusting to optimal corn price and agencies' inventory target before the harvest period. This makes the price inflexible. More so, the very short-run price change is not counterfactual evidence of this assumption. Using the sticky model as developed in the study, there is a clear indication that corn prices are inflexible. Table 4 showing the corn-price inflation from 1990 to 2027 including the 10 yearsout-of-sample forecast reveals clear evidence of infrequent changes in prices. It was defended earlier that there is market information asymmetry that poses expectation constraints on corn traders (including the farmers). The 10 years out of sample forecast predict a little change for the next 10-year corn trading confirming the price-sticky theoretic framework suggested at the genesis of this work. The corn-inflation is predicted to gravitate between $3.42 \%$ and $3.64 \%$ for 10 years at $0.02 \%$ inflation every trading year.

Table 4 For Ten (10) Year Out of Sample Inflation Forecast

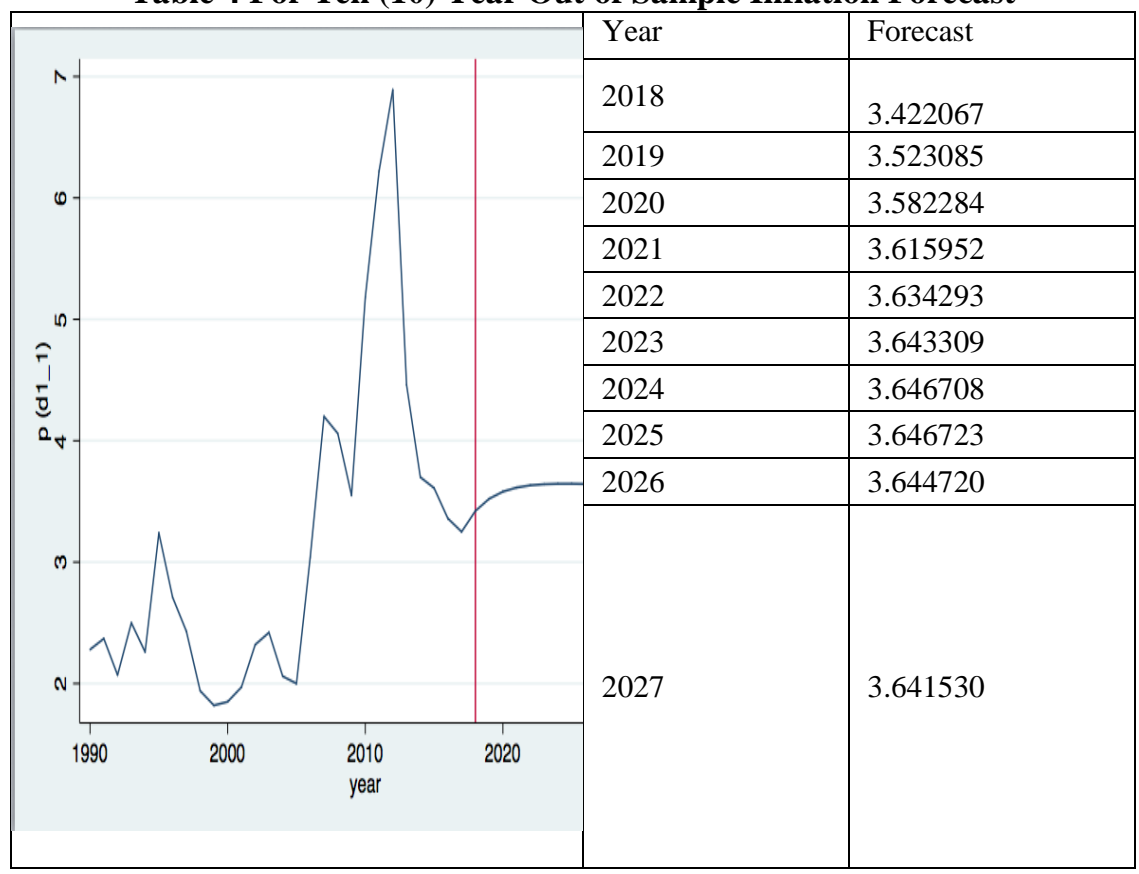

Source: Author's computation 
Shobande, O.A., Shodipe, O.T., (2021)

Price stickiness in US-corn market: evidence from DSGE-VAR simulation

\section{Conclusions}

At the onset, the study advocated price inflexibility in the US corn market. Various reasons were highlighted such as the market imperfection, non-encompassing price support program participation by farmers and inventory target by the government agencies. All these fundamental factors cause infrequent changes for several periods. The study however admitted that there is very short-run fluctuation, but this is dissipated over time. The empirical result is consistent with this assumption and the 10-year forecast, which shows another clear indication that corn-price inflation would be relatively inflexible for the next 10 years. This finding thus shed light on the effectiveness of the government price support programs geared towards putting farms in the hand of the households. The conclusion of the study depends on the behavior of price inflation of the agricultural inputs used by farmers in the production process.

It is plausible to argue that the inflation differential between corn-price and the corn input price would extensively determine if a farmer would continue to produce or sell its farm estate to firms. Higher corn input inflation would lead to less corn profit and more farms would be taken over by firms. Considering this possible outcome in any trading year, several government price support programs should be systematically aligned with the rate of inflation in the agricultural input sub-sector. The market policy program piloted to encourage family farms production should be geared towards both corn-price and input inflation stabilization. We verified that demand shock can potentially have very sensitive effects on output and prices.

\section{Acknowledgments}

The authors thank the anonymous reviewers and editor for their valuable contribution.

\section{Funding}

This research received no specific grant from any funding agency in the public, commercial, or not-for-profit sectors.

\section{Author Contributions}

All authors contributed equally to this article.

\section{Disclosure Statement}

The authors have not any competing financial, professional, or personal interests from other parties. 
Shobande, O.A., Shodipe, O.T., (2021)

Price stickiness in US-corn market: evidence from DSGE-VAR simulation

\section{References}

1. Abbott, P., Boussios, D., Lowenberg-Deboer, J., (2019), Valuing Public Information in Agricultural Commodity Markets: WASDE Corn Reports. Economics Bulletin, 39(3), 1-45

2. Adjemian, M.K., Smith, A., (2012), Using USDA forecasts to estimate the price flexibility of demand for agricultural commodities. American Journal of Agricultural Economics, 94(4), 978-995. https://doi.org/10.1093/ajae/aas032

3. Adjemian, M.K., Smith, A., Adjemian, M.K., Smith, A., (2012), Agricultural \& Applied Economics Association Using USDA Forecasts to Estimate the Price Flexibility of Demand for Agricultural Commodities. American Journal of Agricultural Economics, 94(4), 978-995. https://doi.org/10.1093/aiae/aas032

4. An, X., Deng, Y., Gabriel, S.A., (2011), Asymmetric information, adverse selection, and the pricing of CMBS. Journal of Financial Economics, 100(2), 304325. https://doi.org/10.1016/j.jfineco.2010.12.002

5. Anderson, E.T., Simester, D.I., (2010), Price Stickness and customer Antagonism, 125(2), 729-765

6. Angeletos, G.-M., Lao, J., (2009), Incomplete Information, Higerh Beliefs and Price Inertia. NBER Working Paper 15003, 52(1), 1-5

7. Arnade, C., Cooper, J., (2013), Price Expectations and Supply Response. 2013 Annual Meeting, August, 4-6

8. Baumeister, C., Ellwanger, R., Kilian, L., (2017), Did the Renewable Fuel Standard Shift Market Expectations of the Price of Ethanol? Ssrn. https://doi.org/10.2139/ssrn.2893037

9. Brzoza-Brzezina, M., Kolasa, M., Makarski, K., (2013), The anatomy of standard DSGE models with financial frictions. Journal of Economic Dynamics and Control, 37(1), 32-51. https://doi.org/10.1016/j.jedc.2012.06.008

10. Burfisher, M.E., Hopkins, J., (2004), Decoupled payments in a changing policy setting. Economic Research Service, (838), 62

11. Calvo, G.A., (1983), Staggered prices in a utility-maximizing framework. Journal of Monetary Economics, 12(3), 383-398. https://doi.org/10.1016/03043932(83)90060-0

12. Chen, S., Li, Z., Zeng, Y., (2014), Optimal dividend strategies with timeinconsistent preferences. Journal of Economic Dynamics and Control, 46, 150172. https://doi.org/10.1016/j.jedc.2014.06.018

13. Frankel, J.A., (1986), Expectations and commodity Price Dynamic: The Overshooting Model, American Journal of Agricultural Economics, 68(2), 344348

14. Hart, C.E., Babcock, B.A., (2005), Loan Deficiency Payments versus Countercyclical Payments: Do We Need Both for a Price Safety Net? Retrieved from http://www.card.iastate.edu/publications/synopsis.aspx?id=573 
Shobande, O.A., Shodipe, O.T., (2021)

Price stickiness in US-corn market: evidence from DSGE-VAR simulation

15. Holt, M.T., Johnson, S.R., (1989), Bounded Price Variation and Rational Expectations in Endogenous Switching Model of the U.S. Corn Market. The Review of Economics and Statistics, 71(4), 605. https://doi.org/10.2307/1928102 16. Johnson, M.D., Plott, C.R., (1989), The effect of two trading institutions on price expectations and the stability of supply-response lag markets. Journal of Economic Psychology, 10(2), 189-216. https://doi.org/10.1016/01674870(89)90019-6

17. Lucas, R., (1976), Econometric Policy Evaluation: A Critique. CarnegieRochester Conference Series on Public Policy, 1, 19-46

18. Martín-Rodríguez, G., Cáceres-Hernández, J.J., (2012), Forecasting pseudoperiodic seasonal patterns in agricultural prices. Agricultural Economics (United Kingdom), 43(5), 531-544. https://doi.org/10.1111/j.1574-0862.2012.00601.x

19. Meade, B., Puricelli, E., McBride, W., Valdes, C., Hoffman, L., Foreman, L., Dohlman, E., (2016), Corn and soybean production costs and export competitiveness in Argentina, Brazil, and the United States. USDA Economic Information Bulletin, 154, 1-52. Retrieved from https://ssrn.com/abstract=2981675 ODI. (2010). What caused the food price spike of 2007 / 08? Lessons for world cereals markets. UK-Aid, 44(0), 1-15

20. Peterson, H.H., Tomek, W.G., (2005), How much of commodity price behavior can a rational expectations storage model explain? Agricultural Economics, 33(3), 289-303. https://doi.org/10.1111/j.1574-0864.2005.00068.x

21. Phuong, V., Le, M., Minford, P., (2005), Calvo Contracts - Optimal Indexation in General Equilibrium. Discussion Paper Series- Centre for Economic Policy Research London, ALL

22. Rabanal, P., Rubio-Ramírez, J.F., (2005), Comparing New Keynesian models of the business cycle: A Bayesian approach. Journal of Monetary Economics, 52(6), 1151-1166. https://doi.org/10.1016/j.jmoneco.2005.08.008

23. Rani, S., Shah, H., Ali, A., Rehman, B., (2012). Growth, Instability and Price Flexibility of Major Pulses in Pakistan. Asian Journal of Agriculture and Rural Development, 2(22), 107-112

24. Schnepf, R., (2006), Price determination in agricultural commodity markets: A primer. Congressional Research Service - Report for Congress, 39. Retrieved from http://nationalaglawcenter.org/wp-content/uploads/assets/crs/RL33204.pdf

25. Schreiber, P., Weber, M., (2016), Time inconsistent preferences and the annuitization decision. Journal of Economic Behavior and Organization, 129, 3755. https://doi.org/10.1016/j.jebo.2016.06.008

26. Sumner, D.A., Mueller, R.A.E., (2006), Are Harvest Forecasts News? USDA Announcements and Futures Market Reactions. American Journal of Agricultural Economics, 71(1), 1. https://doi.org/10.2307/1241769

27. Tack, J.B., Ubilava, D., (2013),. The effect of El Niño Southern Oscillation on

62 Sciendo Studia Universitatis "Vasile Goldis" Arad. Economics Series Vol 31 Issue 2/2021 ISSN: 1584-2339; (online) ISSN: $2285-3065$

Web: publicatii.uvvg.ro/index.php/studiaeconomia. Pages $45-63$ 
Shobande, O.A., Shodipe, O.T., (2021)

Price stickiness in US-corn market: evidence from DSGE-VAR simulation

U.S. corn production and downside risk. Climatic Change, 121(4), 689-700. https://doi.org/10.1007/s10584-013-0918-x

28. Taylor, J.B., (1980), Aggregate Dynamics and Staggered Contracts. Journal of Political Economy, 88(1), 1-23

29. Von Mouche, P., Quartieri, F., (2013), On the uniqueness of Cournot equilibrium in case of concave integrated price flexibility. Journal of Global Optimization, 57(3), 707-718. https://doi.org/10.1007/s10898-012-9926-z

30. Woodford, M., Fair, R., Giannoni, M., Mishkin, R., Nelson, E., Preston, B., ... Taylor, J. (2007), Forecast Targeting As a Monetary Policy Strategy , 21(4), 3-24 31. Xia, T., Li, X., (2010), Consumption inertia and asymmetric price transmission. Journal of Agricultural and Resource Economics, 35(2), 209-227 